\title{
Urban poverty in Switzerland: exclusion processes and public policy
}

\section{Antonio de Cunha}

\section{Introduction}

Cities worldwide are affected by the profound transformation in modes of production and in the distribution of wealth. The new international division of labor has led to the renewed strength of economic actors, and the extraordinary mobility of capital has been accentuating existing problems of economic dependence. New production and communication technologies have been revolutionizing the organization of labor and production and have been transforming lifestyles and territories. While the economy is globalizing and modernizing, the world is metropolitanizing, and cities have become the principle locales for these transformations.

Cities in which the majority of the world's population now resides have never been so wealthy, so comfortable, so well equipped and so diverse. Today's cities are foci of technologies that overcome distance and offer new services for the globalizing economy. Cities also play a role of "uncertainty reducers" because they allow firms to adjust to changes easily: not only can entrepreneurs rely on a broad supply of public and private services, but also can they draw on an abundant and diversified labor market (VELTZ 1993). Thus, cities continue to be an ideal terrain for profitable investments. These, in turn, impose lifestyles centered on the isolated, abstract, anonymous individual, a replaceable support for skills that can be mobilized at any moment by the indifferent and equally anonymous urban labor markets oriented towards greater flexibility. Although cities continue to be major centers of innovation and economic growth they have also become factories of exclusion (ClERC 1993), though:

- the shift away from stable towards more flexible forms of employment,

- the individualization of societies and

- the loss of social protection associated with the crisis of the welfare state (CASTEL 1995).

The "network societies" of the information age (CASTElls 1996) are urban societies threatened by increasing inequalities and the disintegration of social bonds (RACINE 1994; BASSAND 1997; LIPIETZ 1997). Switzerland, too, is subject to these tendencies (Cunha 1994; Cunha, Leresche \& Vez 1998).

\section{New poverty in Switzerland: the end of the Swiss model}

Up until the late 1980s, Switzerland passed through periods of crisis with practically no unemployment. The "Swiss model" meant prosperity, well-being and full employment. This situation has changed since the early 1990s. Globalization, the dismissal of knowledge and the deskilling of trades and a regime of economic growth without corresponding growth in employment have adversely affected Swiss society. These changes manifest themselves in different ways: technological change, flexible management and production and the cumulative effects of budgetary restrictions act on society as a whole; unemployment, precariousness and exclusion, however, have a selective impact in a labor market that has become essentially urban.

In Switzerland, as elsewhere, a dual society with segmented labor markets emerge. There is a smaller segment of the technology, communications and information oriented high skilled and a larger segment of rather low-skilled labor. Known as the Microsoft-McDonalds phenomenon, this labor market segmentation has become the dominant component of social and spatial structure (CUNHA, LERESCHE \& VEZ 1997).

\subsection{Urban inequality, poverty and exclusion}

Switzerland reveals an emergence of inequalities, poverty and exclusion. There is growth of:

- long-term unemployment,

- job-seekers no longer eligible for unemployment benefits and

- the number of people in financially precarious situations.

The erosion of the social fabric corresponds with the degeneration of the places in which people construct their daily lives. As recent studies (LEU, BURri \& Priester 1997, LIEChTI \& KNÖPFL 1998 for a nationwide assessment) show, precariousness, poverty and exclusion do not constitute a specifically urban problem in Switzerland. It is in the urban agglomerations, however, that the "new social question" has become a new collective concern. Poverty lodges itself there, in the heart of abundance itself.

Cities are complex, ambivalent and uncertain social systems. They are centers of economic and symbolic accumulation around which entire regions are structured. Cities record all of the dysfunctions and all of the ruptures of collective life. They are thus 
called upon to play a privileged role in the application of public regulatory interventions designed to prevent and to control the processes of exclusion.

\subsection{Studying urban poverty as a social construction}

Poverty has become a central issue in public debate and numerous studies since the late 1980s. MaRAZzI's (1986) pioneer study generated little interest initially, as it seemed incongruous to assert the existence of poverty in the richest country of the world. Yet, its contribution is profound because it introduced the problem of poverty by treating it as a phenomenon generated by social structures and at the center of society, rather than as the particular characteristic of a marginal group. Thus, the pertinence of the problem of "new poverty" was demonstrated in a country which, unlike its European neighbors, had not yet been confronted with growing unemployment. Studies in other cantons supported this notion (HAINARD 1990; PERRUCHOUDMASSY 1991; JOLIAT 1992; FüGLISTALER \& HOHL 1992; FARAGO \& FÜGLISTALER 1992; BINDER \& UlRICH 1992; FLÜCKIGER 1996). Rising economic problems in the urban agglomerations made some cities assess their social situation (Corajoud \& Piotet 1994; Cunha et al. 1995). This clearly showed that poverty is not a scientific concept that can be assessed with absolute accuracy. According to different studies conducted on a global and local scale, the percentage of the population that officially qualify as poor falls into the 6 to $14 \%$ range. This, however, does not include those with incomes just above the poverty line.

Although there were a variety of definitions and methodological approaches in Swiss poverty studies they did provide a deeper understanding of the different manifestations of poverty. Hence, they permit the analysis of underlying causes and show the different ways in which people in precarious situations experience the processes of impoverishment and exclusion. Poverty, thus, is a multidimensional phenomenon, which effects all spheres of existence: lack of resources, absence of control over living conditions, social disqualification, and the impossibility of making plans for the future. In sum, these studies also opened up a debate on the inadequacy of the Swiss social security system and on the need for inventive solutions.

Poverty has a thousand faces and generates a thousand policy responses, all of them less than perfect. The fact that poverty and exclusion are only partially understood calls for a pluralistic approach studying these issues. A pluralistic approach mobilizes diverse definitions and analytical techniques in a complementary perspective in order to comprehensively understand the manifestations of urban poverty.
The study presented in this paper was mandated by the City of Lausanne. It specifically tried to address the dimensions of poverty in the capital of the Canton of Vaud and to establish a profile of the populations concerned, with a view on possible policy action. This involved, of course, quantifying poverty, but also highlighting vulnerable groups, and identifying the processes and factors leading to insecurity in the urban environment.

The following sections present the principal concepts that were employed in this study, based on a number of working hypotheses. Also addressed are some methodological aspects as they apply to the analysis of urban precariousness. Last, this paper discusses the political struggle against exclusion over the last few years, and addresses the role of local authorities in social assistance, professional reinsertion, and financial aid to low-income groups.

\section{Urban poverty and social exclusion: a pluralistic approach}

This analysis utilized a combination of three approaches to poverty:

- the "resources approach",

- the "conditions of existence" approach

- the "poverty as a process and experience" approach.

The first two concepts characterize urban poverty and the third reconstructs individual trajectories of social disqualification. Thus, the processes can be uncovered underlying the weakening of integration and the experiences of people confronted by insecurity and exclusion.

\subsection{The resources approach}

According to DickEs $(1984,1990$ a) definitions of poverty may:

- address poverty as a condition or as a process,

- differ in their "absolute" or "relative" character

- focus on revenue alone or incorporate a wider conception of resources (cultural poverty, poverty of relationships),

- analyze poverty from the point of view of living conditions, based on "objective" statistical criteria, or based upon individuals' perceptions of their situation.

Relative poverty as compared to the average wellbeing highlights the importance of the lifestyle specific to a society. This contextual relativity is directly linked to an interpersonal relativity. In a hierarchical society, individuals are poor in relation to others. Contextual relativity, thus, is a phenomenon that reveals the effects of unequal access to 
resources. Poverty is essentially the result of social relations: there are poor people only because there are others who are rich.

In highly monetized societies the concepts of relative or absolute poverty relate to deficiencies in monetary resources. The notion of revenue remains, therefore, fundamental materially and methodologically. In an urbanized society where money is the principal mediator that ensures existence, having a minimum disposable income is of critical importance. Threshold levels pertaining to low income allows to identify those groups within a population that are at the highest risk of exclusion.

Hence: in highly monetized societies, the volume of economic resources determines the relative position of individuals on a continuum measuring different poverty situations; in this unidimensional but significant perspective, relative poverty is necessarily defined in relation to an income level that tends to increase along with the general increase in wealth.

Along this continuum, there are different degrees of economic insecurity. One can, for example, speak of "low-income groups", of groups in precarious financial situations, or of the poor in the strictest sense of the term. Different studies adopt monetary measures considered in international comparisons to reveal situations of relative and/or absolute poverty. The threshold of $50 \%$ of average or median income per person (i.e. household member) is often chosen. Choices of this type are as arbitrary as they are necessary when beginning empirical research or defining eligibility for social policy measures.

The Swiss Conference of Social Institutions places the poverty line at approximately 1800 Swiss francs per month for a single person household. The limit below which complementary benefits are paid, and which constitutes a sort of official poverty line for people of retirement age, is 2200 francs of disposable income per month for a single houseold. When applying these criteria to Switzerland, 680,000 people are living in a financially precarious situation. This is not an abstract or theoretical precariousness. Rather, it refers to a situation where the conditions of existence are below the level authorities consider a minimum and below which one has the right to assistance. In Lausanne, $13 \% \quad(=7402)$ of the households live below this threshold level.

In a free market society, it is essentially income level that establishes "poverty". However, income and resources translate into other aspects as well, notably in terms of qualification and degree of social integration. Still viewed from the angle of personal resources, poverty thus becomes a multidimensional concept, measurable through an accumulation of disadvantages.
This leads to a second proposition that may help us understand urban poverty: situations of poverty may combine a triple deficit in economic resources, in individual cultural capital (level of education), and in the degree of integration in urban (and family and social) life. It is by taking jointly into consideration these three types of resources (economic capital, cultural capital and relational capital) that it becomes possible to explain the diversity of urban poverty.

Poverty comprises two dimensions: total volume of resources or capital and the relative weights of the different types of capital individuals possess. Hence, poverty can be analyzed using all three arguments (the three types of capital), only two arguments (two types of capital), one alone, or none. In total, four types of vulnerability were identified within a representative sample of $20 \%$ of the households in Lausanne (11,300 households) at the lower end of the income scale (Tab. 1).

\section{Sociodemographic profiles}

of low income households

The risk factors associated with the different degrees of vulnerability are multiple, which is indicative of the great heterogeneity within lowincome groups. The sociodemographic profiles of the different subgroups of low-income households are significantly different. The active households in the two most vulnerable groups suffer from finan-

\begin{tabular}{|l|c|c|c|l|}
\hline $\begin{array}{l}\text { Degree of } \\
\text { vulnerability }\end{array}$ & $\begin{array}{l}\text { Number of } \\
\text { households }\end{array}$ & $\begin{array}{l}\% \text { of total } \\
\text { sample }\end{array}$ & $\begin{array}{l}\% \text { of house- } \\
\text { holds in } \\
\text { Lausanne }\end{array}$ & $\begin{array}{l}\text { Disposable } \\
\text { income/unit of } \\
\text { consumption } \\
\text { in low-income } \\
\text { households } \\
\text { (in Sfr.) }\end{array}$ \\
\hline $\begin{array}{l}\text { Very } \\
\text { vulnerable }\end{array}$ & 1400 & $13 \%$ & $3 \%$ & $1600 .-$ \\
\hline Vulnerable & 3600 & $32 \%$ & $6 \%$ & $2010 .-$ \\
\hline $\begin{array}{l}\text { Slightly } \\
\text { vulnerable }\end{array}$ & 4500 & $40 \%$ & $8 \%$ & $2430 .-$ \\
\hline $\begin{array}{l}\text { Very slightly } \\
\text { vulnerable }\end{array}$ & 1800 & $16 \%$ & $3 \%$ & $2850 .-$ \\
\hline Total & 11300 & $100 \%$ & $20 \%$ & $2260 .-$ \\
\hline
\end{tabular}

1 Disposable income per consumption unit $=($ total net revenue taxes)/family equivalence coefficient, where the family equivalence coefficient refers to a term borrowed from family budget analysis that attributes different weights to the consumption of each household member ( 1.0 for the first adult, 0.7 for the second adult, 0.5 for a child, etc.). A household composed of two adults and one child would have a coefficient of 2.2 , as an example.

Tab. 1: Disposable income per unit of consumption in low-income households in 1994

Revenu disponible par unité de consommation dans les foyer à bas revenu 1994

Verfiigbares Einkommen pro Verbrauchseinheit in Haushalten mit unterem Einkommen 1994 
cial poverty but also from job insecurity $(25 \%)$. The average age of the head of household is relatively high. Widows/widowers and divorcees are more widely represented than singles or couples with children. Foreigners are also over-represented. It is obvious that the "very vulnerable" population is heavily impacted by the disintegration of social bonds. $60 \%$ of the individuals belonging to this group declared that they have no one in their entourage to help them out in case of difficulties. In this group on the edge of exclusion, one rarely finds middle or senior executives in search of employment, but rather manual laborers with little or no training.

Level of training and degree of integration in the system of production remain the cornerstones of social stratification and access to income. Detailed analysis of the socioprofessional characteristics of the other groups, however, reveal that poverty is no longer incompatible with stable employment (salaried or working poor) nor with high qualifications (new poor).

The most disadvantaged groups are generally located in the neighborhoods to the west of the city, or in central neighborhoods of low residential quality. The map localizing the groups most exposed to the risk of poverty coincides to a great degree with location of subsidized housing. Poverty, thus, appears as a geographically concentrated phenomenon, but one that is heterogeneous from a social point of view. Distinct strata exist within the low-income population. This differentiation may imply failure of social policies that are not individualized but rather maintain a universal character.

\subsection{The conditions of existence approach - "under-provisioning" and deprivation}

Different sorts of financial resources or capital translate into different uses individuals may make thereof. Resources are generally active and efficient. They are like trump cards useful for the appropriation of goods and services to satisfy individual demands (Bourdieu, 1987). The notion of "poor resources", "precariousness" or "poverty" thus defined leads directly to the concept of deprivation often employed in the analysis of the most disadvantaged populations.

In his studies on destitution, Nobel Laureate SEN (1983) abandons the term of poverty in favor of that of deprivation, which he uses to accentuate the dimension of accessibility to material or immaterial goods. According to Runciman (1966), the mechanism of relative deprivation relies on a comparison by the Ego between his level of consumption and that of a person or group of persons serving as a reference. Not having access to the same living conditions as the reference group becomes for the Ego a source of frustration and ill-being.
Measurements of urban poverty according to living conditions should not be considered as a competitive, but rather as a complementary approach to the measures of financial, cultural or social resources. Following Hauser (1984), Dickes (1994) discusses the definition of LC-type (living conditions) poverty, distinguishing it from the previous R-type (revenue) poverty. A third proposition may help guide reflections on poverty in this regard.

Poverty is a state of deprivation or under-provisioning in one or more spheres of existence. When describing poverty, it is necessary to take into consideration both personal resources and the conditions of existence (housing, health, leisure, etc.)

From an economic point of view, a poor person is anyone with a low income who is, in addition, "under-provisioned", that is, deprived of goods and services necessary to cover basic needs (BINDER \& UlRICH, 1992). Poverty, thus, is closely associated with the idea of under-provisioning resulting from insolvency. People may be considered to be in a state of deprivation or of under-provisioning if they do not have the same diet, clothing, housing, infrastructure, working conditions, leisure activities, access to health and other services, etc., that are customary, or at least widely diffused in the society in which they live.

Results showed that 7\% $(=3758)$ of Lausanne's households experience under-provisioning in one or more spheres of existence. These households generally judge their situation to be less favorable than that of those close to them. Single-parent families experience the greatest discrepancy in relation to their social or family milieu. In general, rent, expenses for food, health insurance and taxes constitute the principal sources of financial difficulties for a population of which $16 \%$ of the household heads are job-seekers. Within the sample population, one fourth of the tenants pay a rent that exceeds one third of their income. $25 \%(=2847)$ declared to be heavily indebted.

\subsection{Poverty as process and experience: deskilling of labor and social disaffiliation}

The resources and conditions of existence approaches suggest that one is not always born poor, that one can become poor, however, through a combination of multiple factors. There is a consensus that one needs to understand poverty also as a dynamic, evolving process which brings individuals, through progressive and successive disengagements to situations of deprivation and extreme isolation. Indeed, since the beginning of this decade, many authors have concentrated on analyzing the mechanisms that weaken integration in work and social spheres (Castel 1991, 1992, 1995; Paugam 1991, 1993, 1996). Some authors also consider the 
impact of impoverishment on identity, the way the poor experience the degradation of their financial and social situation and the strategies that they adopt in response (Messu 1991; De Gaujelac \& TABOADA LÉONETTI 1994).

The analysis of poverty as a process is concerned with the:

- reconstitution of individual trajectories in order to identify the mechanisms of exclusion,

- practices, aspirations and representations of individuals confronted by increasing insecurity,

- understanding of how individuals experience the processes of exclusion.

In-depth interviews conducted with about thirty people confronted by precariousness allowed to reconstruct and analyze their spatial, professional and social-familial trajectories.

A fourth proposition served to guide this analysis. Swiss economic organization generates insecurity and poverty at the same time that it produces merchandise and wealth; the social organization grants autonomy at the same time that it causes fragility and dependence. Impoverishment results from the processes of the deskilling of labor and the social disaffiliation correlated with the social and economic functioning of urban societies.

The paths that lead to poverty can be envisaged as a conjunction of both the process of deskilling or maladjustment to the labor market resulting eventually in the loss of one's job and income, and a process of disaffiliation. This leads to a weakening of networks, whether they be familial or social, formal or informal, and finally, to a disintegration of social bonds.

Intersecting two axes, an axis of integration through work and an axis of integration through social networks (Fig. 1), one can distinguish five "typical" situations, referring to as many degrees of integration/exclusion: integration, individuation, precariousness, assistance and exclusion. An analysis of the stories recounted during the interviews reveals these situations and the different types of individual trajectories leading to insecurity (Cunha, Leresche \& Vez 1998). Contemporary urban poverty appears to be linked, unquestionably, to two orders of change: first, transformations in the structure of labor and second, social and cultural mutations, such as the weakening of the traditional family bond, the evolution of family structures, and individualization whereby each individual alone is accountable for his own future.

A full understanding of the mechanisms leading to increasing precariousness also requires an analysis of life experiences, through observation of aspirations, practices and the capacity to make plans for the future. Testimonies gathered during the study

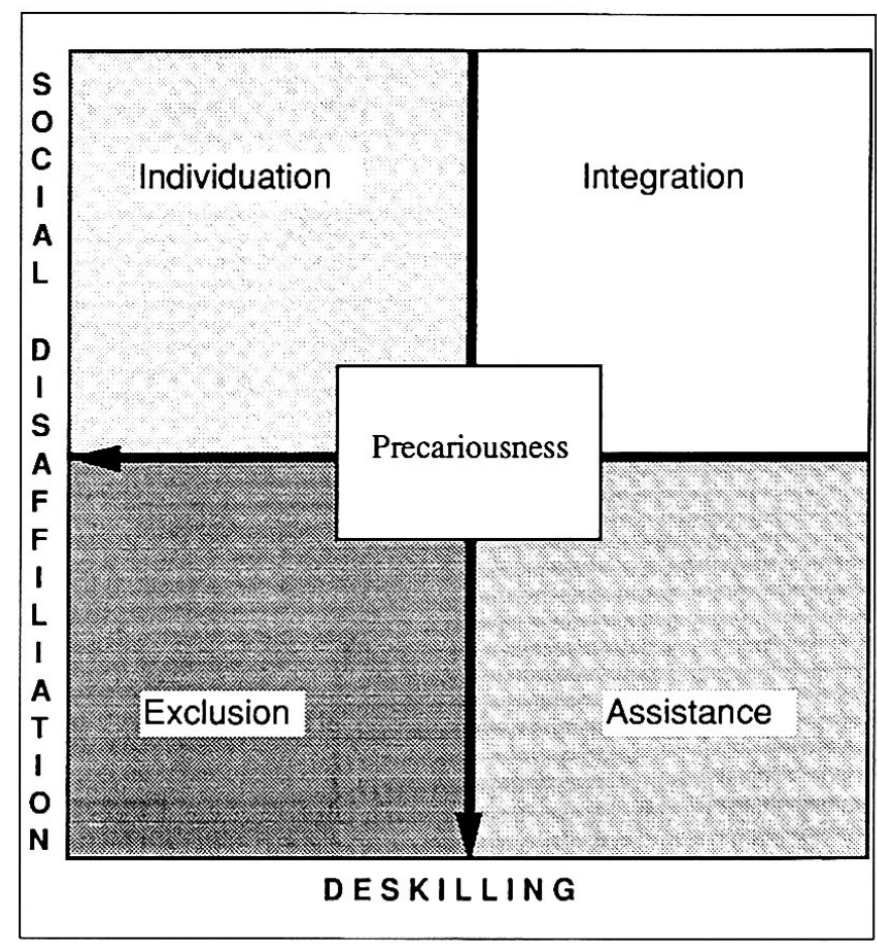

Fig. 1: Exclusion process: weakening of social networks and deskilling

Processes d'exclusion: affaiblissement des réseaux de sociabilité et déqualification du travail

Ausgrenzungsprozess: Schwächung sozialer Netze und Verlust von Arbeitskompetenz

reveal that those facing increasing insecurity in their conditions of existence experience not only a drop in status and progressive marginalization, but also experience an identity crisis. Individuals in precarious situations find themselves stigmatized, marginalized and discredited through their lack of employment, their recourse to social services, or by reason of their non-traditional family situation. Jobs, in turn, are factors of identity, permitting access to income, social recognition and integration in the city, even though their real integrative capacity may be diminishing.

Faced with stigmatization, and given their own norms and the dominant values concerning employment, some people experience their professional inactivity and the recourse to social services above all in terms of shame and guilt. The testimonies gathered nonetheless reveal distinct methods for dealing with this situation: in the majority of cases, these feelings push people into withdrawal, leading them to curb their social lives in order to avoid the disapproving eyes of others. In some cases, the individuals manage to resist the effects of the loss of status, preserving themselves from a loss of identity through a rationalization of their experiences. 
Examples of the techniques of rationalization emerge from the records of the interviews (CunHA, LERESCHE \& VEZ 1998). For some, the loss of their job represents an opportunity to reinvest in their families, often neglected due to the demands of a professional career. It appears that individuals with a superior level of training tend to turn to their advantage a precarious situation that they consider to be transitory. They experience their situation as the opportunity to establish a new identity, and to adopt a new lifestyle, whereas the more destitute encounter more difficulties in rearranging their identity and their lifestyles.

For all, the restriction of their social lives and their space is accompanied by an inability to imagine their future. Even if these individuals express a veritable desire to reestablish financial independence and to rediscover a useful role in the city, they live from day to day, as public assistance is perceived to be insufficient to truly escape the vicious circle of insecurity.

By reason of its characteristics, traditional social aid has its limits. Access to this aid is not a right, and aid is in the form of strictly economic assistance measures, which do not include any real steps that would lead to the professional reinsertion and the autonomy of the individuals concerned. Indeed, it is through recourse to social aid that individuals find themselves recognized and designated as poor. Those concerned perceive the recourse to social aid as a concrete expression of their downfall, of their slide into the universe of those receiving handouts. The individual who receives welfare assistance sees himself labeled with an identity that was hitherto foreign to him (AuTÈs 1992).

The multiple factors at play in the processes of disqualification and disaffiliation attest to the existence of multiple life experiences. This thus confirms the necessity of envisaging personalized actions as well as diverse and/or regional policies of reinsertion.

\section{By Way of a Conclusion:}

\section{Urban Poverty, Exclusion and Public Policy}

\subsection{New policy concerns}

The city is the epicenter of poverty and of exclusion (Donzelot \& Estèbe 1994). In Switzerland, cities show the greatest increase in the number of job seekers and in the length of the period of unemployment. It is also in the large cities that meeting the costs of living becomes more problematic given declining purchasing power. Increasing job insecurity is reflective of a heterogeneous society with a "top" and a "bottom", an "inside" referring to the professionally and socially inte-

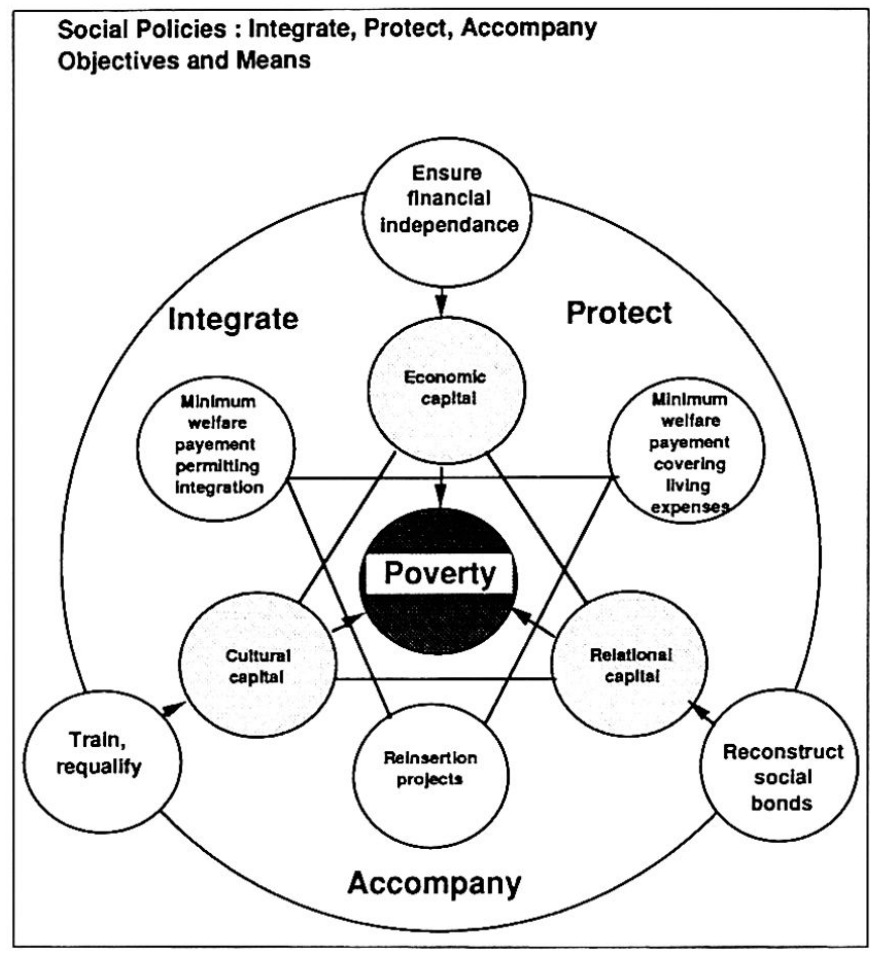

Fig. 2: Multiple instruments constructed around three objectives

Des instruments multiples construits autour de trois objectifs fondamentaux

Flankierende Massnahmen zur Erreichung dreier grundlegender Zielsetzungen

grated individuals, and an "outside", home to the "excluded". Urban societies, then, are divided by a symbolic line into those who have a place in society and those who seek such a place. It is in urban agglomerations that isolation and exclusion are felt most strongly. For some, the city encourages the development of relationships, for those more vulnerable to the dissolution of social bonds, the city becomes a place of anonymity and solitude.

The social situation in Swiss cities does not seem as alarming as in neighboring countries where the social and spatial fractures are more visible. However, Swiss economic and demographic developments call for greater intervention and regulation. Although there are social solidarity mechanisms that combine diverse instruments at the federal, cantonal and communal level these mechanisms no longer function efficiently against the structural causes of the various forms of insecurity and exclusion, or against their consequences. The more general social security instruments were not designed for and, therefore, do not adequately take into consideration the structural transformations in family and social structures and longterm unemployment (GiLliand 1990). In addition, 
economic recovery does not necessarily reintegrate those excluded into gainful employment, as can be seen in other countries.

This poses a particular challenge to public policy at a time in which the welfare state embraces the "lean management" model and public spending is being reduced. One might argue, however, that what is needed most is not an ultraminimal state and measures of austerity but rather a reorientation of social security systems. This means to:

- reaffirm the primacy of politics over spontaneous economic movement. This implies to relegitimize the role of the state, reestablish public intervention morally and intellectually,

- implement new transversal social policies focussed on financial aid, professional reinsertion and on social assistance,

- establish and integrate national approaches to target groups with local approaches based on activities and projects,

- develop a national urban policy anchoring the fight against poverty in urban and metropolitan areas with the mediation of the state.

Three complementary requirements can be conceived (Fig. 2):

- a guaranteed minimum income which will insure solvency and which will cover living costs,

- an offer of training and professional reinsertion that combines social action and economic development (off-the-job training, training in alternation, for example employment programs, temporary placements, public works programs), promotion of activities that could be transformed into permanent employment, individualized training credits, etc.),

- development of integrative and projective, regionalized people and poverty-oriented policies to cope with the true extent, multiple faces of poverty and processes of impoverishment in cities and urban agglomerations.

These three types of social policy target also address:

- economic capital by ensuring a certain degree of financial autonomy,

- cultural capital through preventative training or requalification of individuals and

- social capital by reestablishing social bonds through the affirmation of fundamental rights, based on the principle of the individual as actor in his plan for economic, professional or social reintegration.

Urban poverty can be considered as a denial of citizenship. Policies of reintegration specifically concern access to new social rights and access to re- sources. The latter are not limited to financial aid, but also include jobs, social relations, and symbols of status that open the door to independence and autonomy.

\subsection{The case for territorial social policy}

Territorialization of such policy reflects two types of reasoning (UnIOPPS 1993): First, public policy implies a localized organization of interventions aimed at different categories of the population, interventions which are elaborated at other decisional levels according to tested forms. Second, territorialization is a new approach to the management of populations, based on a general transformation of social aid devices. In this context, cities and urban agglomerations have an important role to play in the realm of public policy. The rationale for an intervention at the level of the urban authorities is based on several observations:

- The welfare state can no longer adequately deal with all types of social dysfunction and rising poverty.

- In urban agglomerations, social bonds are conjugated with proximity; in order to be efficient, there is a need for physical proximity between the public service operators, the providers of reintegration mechanisms and the recipients of such services.

- Mobilizing the personal resources of individuals in precarious situations can only be effective if coupled with the resources of the local environment.

- The urban agglomeration appears to be the geographic scale best permitting local actors to form partnerships around plans for reinsertion or joint economic development.

Directly linking the economic and social spheres, however, and developing actions at the level of the urban areas, is not without ambiguities:

- Neither the state nor local public administration can impose on firms, whether it involves professional reinsertion, organization or sharing of work schedules.

- The domains of professional reinsertion are limited because of the mismatch between the supply of temporary measures for reinsertion and permanent needs, and between the public policy reactions to economic fluctuations and long-term structural change.

- Local solidarity cannot totally replace national or cantonal solidarity; cities and agglomerations do not possess the human, technical or financial resources necessary to ensure the regulatory role they are called on to play. 
The reflections on an urban social policy underscore a decisive aspect in the debate over the "best state". Local solidarity cannot entirely replace cantonal or national solidarity. One cannot exonerate the central services of the state from its responsibilities for the social problems of urban municipalities. The state must use its means to offer greater local benefits flexible, sufficient and diversified enough to allow for multiple strategies for reintegration and individualized assistance.

The prevention of poverty and exclusion also requires the city to provide greater social regulation and to develop its own policy. This solution, too, has its limits: lacking human and financial resources as well as adequate management structures, cities are rarely in a position to take up the challenge. The field is wide open, however, to reflection on comprehensive urban development and the articulation of the role of different actors at different levels of intervention. Urban governance and the role of the central state are at the heart of the urban development and poverty problems (CUNHA, LERESCHE, VEZ 1998). To address these adequately implies continued debate on the division of labor and sharing of responsibilities, the division and redistribution of tax revenues through fiscal reforms and through decidedly social policies.

\section{Literature Cited}

AutÈs, M. (1992): Travail social et pauvreté. Paris. BASSAND, M. (1997): Métropolisation et inégalités sociales. Presses polytechniques et universitaires romandes, Lausanne.

Binder, J. \& W. UlRich (1992): La pauvreté dans le canton de Berne. Direction de l'hygiène publique et des oeuvres sociales du canton de Berne.

Bourdieu, P. (1987): Choses dites. Paris.

CASTEL, R. \& J.-F. LAÉ (1992): Le revenu minimum d'insertion. Une dette sociale. Paris.

CASTEl, R. (1991): «De l'indigence à l'exclusion, la désaffiliation. Précarité du travail et vulnérabilité relationnelle.» - In: Face à l'exclusion, le modèle français. Paris.

CASTEL, R. (1995) Les métamorphoses de la question sociale: chronique du salariat. Paris.

Castells, M. (1996) La société en réseaux, L’ère de l'information. Paris.

Clerc, D. (1993): La fabrique des exclus. - In: Le temps des exclusions, Le Monde diplomatique, Manière de voir 20, Novembre: 14-16.

Corajoud, G. \& G. Piotet (1994): La précarité des conditions de vie dans quatre communes vaudoises, Université de Lausanne, Institut des sciences sociales et pédagogiques.

Cunha, A. (1994): L'avenir de la Suisse urbaine: changement technologique, métropoles informa- tionnelles et développement territorial. - In: Geographica Helvetica 2: 53-62.

Cunhs, A., Vez, I., Marcel, J., Pedrazzini, Y., GilLiARD, P., Busset, Th., LeRESChe, J.Ph. \& M. BASSAND (1995): Pauvreté urbaine et exclusion sociale: conditions d'existence et vécus des populations à faibles revenus, Rapport de recherche 125, IREC/ EPFL, Lausanne.

Cunha, A., Leresche, J.-Ph. \& I. Vez. (1998): La pauvreté urbaine, Le lien et les lieux, Ed. Réalités Sociales, Lausanne.

De Gaujelac, V. \& I. Taboada Léonetri (1994): La lutte des places. Insertion et désinsertion. Paris.

Dickes, P. \& J.-C. RAY (1990a): Mesurer la pauvreté ete la précarité par les seuils et les cumuls. Présentation et validation de cés méthodologies. - In: Pauvretés et sécurité sociale. Ed. Réalites sociales. Lausanne: 137-167.

DiCKEs, P. (1990): Pauvreté et conditions d'existence théories, modèles et mesures. - In: Pauvretés et sécurité sociale. Ed. Réalités sociales, Lausanne: 117-135.

Dickes, P., Gailly, B., Hausman, P. \& G. Schaber (1984): Les désavantages de la pauvreté: définitions, mesure et réalités en Europe. - In: Mondes en Développement, no. 45: 131-190.

Dickes, P. (1994): Ressources financières, bien-être subjectif et conditions d'existence. - In: BouchayER, F.: Trajectoires sociales et inégalités. Paris: 179-199.

Donzelot, J. \& Ph. Estèbe (1994): L'état animateur. Essai sur la politique de la ville, Paris.

Farago, P. \& P. Füglistaler (1992): Armut verhindern. Die Zürcher Armutsstudien: Ergebnisse und sozialpolitische Vorschläge. Fürsorgedirektion, Zürich.

FLÜCKIGER, Y. (1996): La situation des chômeurs en fin de droit à Genève. Rapport d'activité 1995 de l'OCDE, Département de l'économie publique, Genève.

Füglistaler, P. \& M. Hohl (1992): Armut und Einkommensschwäche im Kanton St. Gallen. Haupt, Bern.

GILliand, P. (1990): Evolution, perspectives et pistes de réflexions pour la Suisse. - In: Pauvretés at Sécurité sociale, Réalités sociales, Lausanne:296-319. Hainard, F., Nolde, M., Memminger, G. \& M. MICHELONI (1990): Avons-nous des pauvres? Enquête sur la précarité et la pauvreté dans le canton de Neuchâtel. Neuchâtel.

Hauser, R. (1984) Some problems in defining a poverty line for comparative stuides. - In: SAPRLLON, G., dir., Understanding poverty, franco Angelico, Milano: 329-354.

JoLIST, J.-P. (1992): Pauvreté dans le canton du Jura, Service de l'aide sociale. Délémont.

Leu, R. E., Burri, S. T., Priester, T. (1997): Qualité 
de vie et pauvreté en Suisse: aperçu des principaux résultats, FNRS, Berne.

LIECHTI, A. \& C. KNÖPFEL (1998): Les working poor en Suisse: ils ont pauvres et pourtant ils travaillent. (Caritas), Lucerne.

LiPIETZ, A. (1997): La société en sablier, Le partage du travail contre la déchirure sociale, La Découverte. Paris.

MarazzI, C. (1986): La povertà in Ticino. Dipartimento delle opere sociali. Locarno.

Messu, M. (1991): Les assistés sociaux, analyse identitaire d'un groupe social. Toulouse.

Paugam, S. (1991): La disqualification sociale: essai sur la nouvelle pauvreté. Paris.

Paugam, S. (1993): La société française et ses pauvres, Paris.

Paugam, S. (1996): L'exclusion, l'état des savoirs, La Découverte. Paris.

Perruchoud-Massi, M.-F. (1991): La pauvreté en Valais, Département des Affaires sociales. Etat du Valais.

RACINE, J.-B. (1994): La Suisse urbaine à l'orée du 3ème millénaire: risques et défis d'un changement non programmé. - In: Geographica Helvetica 2: 47-52.

Runciman, W. (1966): Relative deprivation and social justice. London.

Sen, A. (1983): A Sociological Approch to the Measurement of Poverty. Oxford Economic Papers $37 / 4$.

UnIOPPS (1995): Accompagnement social et insertion. Paris: Syros.

Veltz, P. (1993): Logiques d'entreprise et territoires: les nouvelles règles du jeu, Les nouveaux espaces de l'entreprise. Paris: Datar.

\section{Summary: Urban poverty in Switzerland: exclusion processes and public policy}

Poverty is lodged in the heart of abundance itself. The weakening of the social fabric is particularly apparent in cities: the deskilling of labor, the decline in social and symbolic status, isolation, and the loss of social protection due to the crisis of the welfare state constitute different aspects of exclusion. Urban poverty also appears as a denial of citizenship. This article applies a pluralistic approach in studying urban poverty. It also suggests organizing principles as a basis for transforming and "territorializing" of public social policy instruments in the city.

\section{Résumé: Pauvreté urbaine en Suisse: exclusion et politiques publiques}

La pauvreté loge au cœur même de l'abondance. Le processus de fragilisation du lien social se marque d'abord dans les villes: déqualification du travail, déclassement social et symbolique, isolement, perte des protections sociales en relation avec la crise de l'Etat-providence sont les différentes faces de l'exclusion. La pauvreté urbaine apparaît aussi comme un déni de citoyenneté. L'article s'attache à montrer l'intérêt d'une approche plurielle de la pauvreté urbaine. Il rend également compte des principes organisateurs à l'origine d'une recomposition et d'une territorialisation des instruments en matière de politique sociale de la ville.

\section{Zusammenfassung: Städtische Armut in der Schweiz: Ausgrenzung und Planungspolitik} Armut gibt es inmitten des Überflusses. Die Schwächung des Sozialgefüges ist besonders ausgeprägt in den Städten: mangelnde Ausbildung, der Verlust des sozialen und symbolischen Status, Isolation und der Rückbau des Sozialstaates und Verlust sozialer Sicherheit bilden verschiedene Facetten der Ausgrenzung. Städtische Armut entwickelt sich zum Verlust von Bürgerrechten. Dieser Aufsatz wendet einen pluralistischen Ansatz an, um die grossstädtische Armut zu erfassen. Er stellt ferner neue Organisationsformen und die Regionalisierung planungspolitischer Instrumente als Lösungsansätze zur Diskussion.

Prof. ass. Dr. Antonio de Cunha, Institut de Géographie, Faculté des Lettres, Université de Neuchâtel, Espace Louis Agassiz 1, CH-2000 Neuchâtel. 
